\title{
Acacia Jacquemontii Ethyl Acetate Extract Downregulated the Hyperglycemia Through Its Modulatory Effects On Endogenous Antioxidant, Anti-Inflammatory And Pancreatic $\beta$ - Cell Regenerative Status in Alloxan Induced Diabetic Rats.
}

\section{Ambreen Mehmood Awan}

University of Agriculture Faisalabad

Wafa Majeed ( $\nabla$ wafa.majeed@uaf.edu.pk)

University of Agriculture Faisalabad https://orcid.org/0000-0001-6983-4474

\section{Faqir Muhammad}

University of Agriculture Faisalabad

\section{Muhammad Naeem Faisal}

University of Agriculture Faisalabad

\section{Research Article}

Keywords: Diabetes mellitus, Acacia jacquemontii, a-amylase, superoxide dismutase, TNF-a, HDL

Posted Date: October 21st, 2021

DOI: https://doi.org/10.21203/rs.3.rs-907011/v1

License: @) (i) This work is licensed under a Creative Commons Attribution 4.0 International License. Read Full License 


\section{Abstract}

Diabetes mellitus is among the world's greatest health hazards. Acacia jacquemontii possess numerous traditional therapeutic uses. This study investigated the role of Acacia jacquemontii ethyl acetate extract (AJEAE) in alloxan induced diabetes in rat model. Current study was performed in two parts, in-vitro, through characterization (HPLC), estimation of TFC, TPC, antioxidant (DPPH assay) and a-amylase inhibitory activities of the studied extract, and in vivo on wistar rats in which animals were divided into five groups NC, DC, GL, AJEAE 250 mg/kg and AJEAE 500mg/ $\mathrm{kg}$. The effects of AJEAE on FBG, serum glucose, insulin, HBA1c, lipid profile, inflammatory cytokines (IL-6, TNF-alpha) and oxidative stress markers (LPO, NO, SOD, CAT, GPx) were evaluated. Our findings confirmed the presence of quercitin, kaempferol, gallic acid, vanillic acid, syringic acid, M-coumaric acid, sinapic acid, chlorogenic acid, cinamic acid and ferulic acid in AJEAE. TFC and TPC in AJEAE were $83.83 \mathrm{mg} \mathrm{GAE} / \mathrm{g}$ and $77.06 \mathrm{mg} \mathrm{QE} / \mathrm{g}$ respectively. Significant inhibition of DPPH and a-amylase activities was exhibited by AJEAE. Alloxan injected rats showed marked hyperglycemia, hypoinsulinemia and increased inflammatory markers levels as compared to normal control. Additionally raised levels of TG, TC, VLDL, LDL, LPO, NO and decreased levels of SOD, CAT and GPx were observed in diabetic rats. AJEAE significantly $(p<0.05)$ improved the aforementioned parameters and the protective efficacy was comparable to glibenclamide. Histopathological findings also evidenced the anti-hyperglycemic properties of AJEAE through regeneration of pancreatic $\beta$ cells. Conclusively our findings demonstrated the antihyperglycemic, antihyperlipidemic, antioxidant, anti-inflammatory and pancreatic beta cells regenerative properties of AJEAE against alloxan induced diabetes.

\section{Introduction}

Diabetes mellitus (DM) is serious and multifaceted metabolic disorder of multiple etiologies, global public health problem, is now emerging as an epidemic worldwide, with intense consequences, both acute and chronic (Salehi et al. 2019). Currently, across the globe there are more than 150 million people with diabetes which seems to be increased 300 million by 2025 (Moradi et al. 2018). Diabetes and its associated micro and macrovascular complications have affected approximately $25 \%$ of world population, so management of diabetes is becoming a socioeconomic challenge world widely (Arumugam et al. 2013). Hyperglycemia, hyperlipidemia, oxidative stress, suppression of antioxidant defense markers and inflammation are the main consequences of diabetes mellitus (Hammeso et al. 2019). Genetic and environmental factors are responsible for development of diabetes in which body cells cannot break down sugar properly due to diminished action of insulin on target tissues resulting in lack of insulin or insensitivity (Salehi et al. 2019).

Multiple antidiabetic regimens are used with different mechanisms to counteract the increased level of glucose. However, long term usage and side effects of available treatment options have increased the demand for novel therapeutically effective agents with minimum side effects for the management of diabetes (Choudhury et al. 2018; Majeed et al. 2018). Medicinal plants have long history of usage and are globally valuable source of new drugs (Chen et al. 2016; Calixto 2019). From different regions of world, different parts of plant have been investigated for antidiabetic activity as different plant contains phenols, carotenoids, flavonoids, terpenoids, alkaloids and glycosides (Moradi et al. 2018). Herbal medicines are most commonly prescribed world wild due to easy availability, low side effects, reasonable price and therapeutic efficacy (Khan MF et al. 2018).

Majority of Acacia species are reported to possess pharmacological activities and have been reported to be effective against a variety of diseases. Acacia jacquemontii Benth locally called as Bhu-banwali, Baonli or Bhunwaliand is native to"Thar desert" of Indo-Pak subcontinent. In Pakistan it is known as 'Bable' or 'kikri' (Ashfaq et al. 2016; Rasool et al. 2016). It was used in the past by Greek practitioners to treat common ailments i.e. stomach pain, kidney stones or 
disorders, toothache, chicken pox, sexual weakness and controlling inflammation (Choudhary et al. 2009; Rasool et al. 2017). The current study was aimed to characterize the AJEAE using HPLC to determine the presence of different bioactive constituents as well as to investigate the ameliorative impact of AJEAE on glycemia,lipidemia, oxidant status, inflammatory markers and pancreatic beta cells apoptosis in alloxan induced hyperglycemia in rats. About our knowledge, no study is till performed in current feature of anti-hyperglycemic potential of Acacia jacquemontii.

\section{Materials And Methods}

\section{Plant collection and extraction}

Acacia jacquemontii leaves were collected from district Bhakkar near Bahawalpur Pakistan. The plant was authenticated by Cholistan institute of desert studies (CIDS) from the Islamia University of Bahawalpur, Pakistan, with voucher number CIDS/ IUB-1901/63. Leaves were cleaned, air dried under shade and finally were grounded into coarse powder using an electric grinder. About $100 \mathrm{gm}$ of powdered material was macerated with ethyl acetate as ratio of 1:4 (W/V) at room temperature with occasional shaking and stirring for 7 days. After that whole mixture was filtered through filter paper and then was concentrated by using a rotary evaporator.

\section{Characterization of AJEAE using HPLC}

High performance liquid chromatography (HPLC) analysis was performed for detection of bioactive compounds. Stationary phase C18 $(5.0 \mu \mathrm{M}) 25 \mathrm{~cm} \times 4.6 \mathrm{~mm}$ ) and SIL-20A auto sampler (Shimadzu Scientific Instruments, Kyoto, Japan) were used. Combination of acetic acid and acetonitrile was used as mobile phase. The flow rate used for analysis was $1 \mathrm{~mL} / \mathrm{min}$. UV-visible detector (SPD-10AV) was used for detection of bioactive compound at the wavelength of $280 \mathrm{~nm}$. Identification and quantification was done by comparison with standards (Imtiaz et al. 2019).

\section{Evaluation of total phenolic and total flavonoid content in AJEAE}

The total phenolic content (TPC) was estimated by using Folin-Ciocalteu method. After preparation of reaction mixture, absorbance was measured at $760 \mathrm{~nm}$ wavelength and results were presented as $\mathrm{mg} \mathrm{GAE} / \mathrm{g}$ (Aryal 2019). The total flavonoid content (TFC) was assessed by Aluminiun chloride colorimetric method. The absorbance was measured at $510 \mathrm{~nm}$ wavelength and results were displayed as mg QE/g of DW (Phuyal et al. 2020).

\section{Evaluation of in vitro antioxidant activity (DPPH Assay)}

The free radical scavenging activity of AJEAE was measured using DPPH as a free radical model (Mogole et al. 2020; Ashraf et al. 2015). Different concentrations of plant extract $(0.125-1 \mu \mathrm{g} / \mathrm{mL})$ were prepared. $1 \mathrm{ml}$ of plant extract was mixed with $3 \mathrm{ml}$ of $5 \mu \mathrm{g} / \mathrm{mL}$ DPPH and then incubated in the dark. Ascorbic acid was used as standard, absorbance was taken at $515 \mathrm{~nm}$ using spectrophotometer and activity was measured by using the formula below:

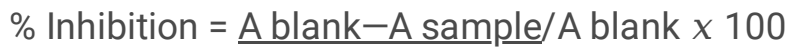

\section{In vitro 囚-amylase inhibition assay}

Alpha-amylase inhibitory assay was done to check the in-vitro antidiabetic activity of AJEAE (Sangeetha and Vedasree2012; Sathasivampillai et al. 2017). $100 \mu \mathrm{L}$ of plant extract was allowed to react with $100 \mu \mathrm{L}$ of $2 \mathrm{mM}$ of phosphate buffer and $200 \mu \mathrm{L}$ of $\alpha$-amylase enzyme. The reaction mixture was allowed to incubate for 20 min and then added $100 \mu \mathrm{L}$ of starch solution (1\%). The similar protocol was carried out for the controls where buffer was used instead of the enzyme. After 5 minutes of incubation, dinitro-salicylic acid reagent (500 $\mu \mathrm{L})$ was mixed in control and 
test, and then placed in boiling water bath for at least $5 \mathrm{~min}$. The absorbance was measured at $540 \mathrm{~nm}$ using spectrophotometer. The inhibitory activity was found by using the equation given below:

$\%$ Inhibition $=$ Absorbance of the control $\otimes$ Absorbance of the test sample/ Absorbance of the control $x 100$

\section{Experimental animals and ethical statements}

Seventy five albino wistar rats (180-200 g body weight) were caged in the animal house of Institute of Physiology and Pharmacology, University of Agriculture Faisalabad. Before start of trail, all rats were acclimatized for 2 weeks.

Experimental protocol was planned according to laboratory animal care guidelines permitted by Graduate studies Research Board, UAF Pakistan. Ethical certificate was issued by institutional biosafety and bioethics committee with letter no. 1739/ORIC for the conduct of in-vivo experiment. Following to the adaptation time, all rats were allocated into five groups, each group having 15 rats.

\section{Induction of experimental diabetes}

Alloxan mono-hydrate (i.p) in $0.9 \% \mathrm{w} / \mathrm{v} \mathrm{NaCl}$ was used to induce diabetes $(150 \mathrm{mg} / \mathrm{kg}$ of $\mathrm{BW}$ ) in all groups except the normal control group. Subsequent to $1^{\text {st }}$ week of the study, glucose levels were measured from all rats according to tail vein method using On-Call Plus (catalogue \# G113-214 $\sqrt{ }$ ) glucometer. For this study, diabetic rats were selected based on the blood glucose level higher than $300 \mathrm{mg} / \mathrm{dl}$.

\section{Treatment protocol and sample collection}

All rats were divided into following groups ( $n=15 /$ group).Group1: Normal Control $(\mathrm{NC})=$ Daily Routine diet + water adlibitum, Group 2: Diabetic control (DC), Group 3: Treated with Glibenclamide (GL; $10 \mathrm{mg} / \mathrm{kg}$ ), Group 4: Treated with AJEAE $(250 \mathrm{mg} / \mathrm{kg})$, Group5: Treated with AJEAE $(500 \mathrm{mg} / \mathrm{kg})$. After completion of $28^{\text {th }}$ day of study, all rats were made overnight fast, anaesthetized (i.p. 3\% sodium pentobarbital) and then sacrificed. Blood samples were obtained, then centrifuged at 4000 rpmfor 10 minutes and obtained serum was stored at $-80{ }^{\circ} \mathrm{C}$ for biochemical studies. For histopathological analysis, pancreatic tissues were preserved in 10\% NBF solution. For biochemical investigations, tissue homogenates were prepared by homogenizing the pancreatic and hepatic tissues in buffer solution containing $50 \mathrm{mMTris}-\mathrm{HCl} \& 1.15 \% \mathrm{KCl}$.

\section{Estimation of serum glycemic markers}

Fasting blood glucose level (FBG) was measured on the $0,7,14,21$ and $28^{\text {th }}$ day of the study via tail prick method by

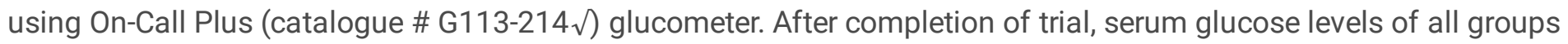
were measured by using rat glucose assay kit of Crystal Chem, USA \# 81693. Serum insulin levels were estimated by using ELISA kit (Thermo Fisher Scientific Catalog\# ERINS). Glycosylated hemoglobin (HbA1c) was assessed byELISA kit (Rat HbA1c ELISA kit catalog \# MBS2509196).

\section{Estimation of serum lipid profile}

Triglycerides (TG), high density lipoprotein (HDL), low density lipoprotein (LDL), total cholesterol (TC) and very low density lipoprotein (VLDL) were measured using previously described method (Arise et al. 2014).

\section{Estimation of serum inflammatory markers}

Serum cytokines (TNF-a, IL-6) were measured by commercially available ELISA kit (RayBio® Rat, RayBiotech, Norcross, GA, USA) according to instruction of manufacturer. 


\section{Estimation of oxidative stress markers}

Oxidative stress was assessed by estimation of lipid peroxidation (malondialdehyde; MDA), nitric oxide (NO), catalase (CAT), glutathione peroxidase (GPx) and superoxide dismutase (SOD) levels in pancreatic and hepatic tissue homogenates using previously defined methods (Eslamiet al. 2015; Rotruck et al. 1973; Takahara et al. 1960; Ohkawa et al.1979; Green et al. 1982).

\section{Histopathological analysis}

For histopathological analysis, portions of pancreatic tissues were fixed in formalin (10\%) for 1 day. Following the fixation, tissues were dehydrated and paraffinized in wax. Serial section were made via microtomy and stained with H\&E dyes for microscopic examination (IRMECO GmbH \& Co, no: IM-91) at magnification power of 40x and snapped using a digital camera.

\section{Statistics}

All data represents at least three autonomous experiments and results were showed as mean \pm S.E. Statistically data were analyzed by analysis of variance (ANOVA) followed by Duncan multiple ranges (Graph Pad Prism Software, version $8.0 .1,244)$. All $p$ values $<0.05$ were considered as statistically significant.

\section{Results}

\section{Characterization of AJEAE by using HPLC}

The flavonoids and phenolics fingerprint of the AJEAE is presented in Fig. 1. The HPLC results of AJEAE revealed the occurrence of different flavonoids and phenolics with 30 peaks and retention times ranging from 2.74 to 31.14 min. Based on the retention times and spectral data, AJEAE showed a UV band at 280nm characteristics for flavonoids and phenolic compounds, possibly quercetin $>$ ferulic acid $>$ sinapic acid > chlorogenic acid > vanillic acid > syringic acid > gallic acid > Kaempferol > M-coumaric acid > cinamic acid (Fig. 1, Table 1).

Table 1

HPLC chromatogram profile of fingerprint of AJEAE

\begin{tabular}{|lllll|}
\hline Compounds & Retention time & Concentration (ppm) & Area (mV.s) & Area (\%) \\
\hline Quercetin & 2.747 & 21.35 & 402.043 & 8.8 \\
\hline Kaempferol & 6.833 & 4.15 & 259.860 & 5.7 \\
\hline Cinnamic acid & 26.667 & 3.47 & 267.572 & 5.8 \\
\hline M-coumaric acid & 20.020 & 3.87 & 323.092 & 7 \\
\hline Gallic acid & 4.253 & 4.25 & 119.224 & 2.6 \\
\hline Syringic acid & 16.273 & 4.35 & 174.160 & 3.8 \\
\hline Vanillic acid & 13.267 & 6.56 & 105.900 & 2.3 \\
\hline Chlorogenic acid & 15.013 & 8.23 & 135.625 & 3.0 \\
\hline Sinapic acid & 24.767 & 17.11 & 489.127 & 10.6 \\
\hline Ferulic acid & 22.140 & 18.41 & 255.889 & 5.6 \\
\hline
\end{tabular}




\section{Total phenol and flavonoid contents}

Total phenolic contents in AJEAE were determined by using gallic acid as the standard. TPC value for AJEAE was $77.06 \mathrm{mg} \mathrm{GAE} / \mathrm{g}$. Total flavonoid contents of the AJEAE were determined by using quercetin as standard. TFC value for AJEAE was $83.83 \mathrm{mg} \mathrm{QE} / \mathrm{g}$.

\section{DPPH activity}

The antioxidant activity of AJEAE was assessed on the basis of their capability to scavenge stable free DPPH radicals. The results clearly specified that AJEAE inhibited free radicals generation based on concentration used (Table 2). AJEAE showed \% inhibition of 69.470 at maximum concentrations of $1 \mathrm{mg} / \mathrm{ml}$ with IC 50 value of $0.77 \mathrm{mg} / \mathrm{ml}$. Reference standard ascorbic acid showed IC50 value of $0.54 \mathrm{mg} / \mathrm{ml}$.

Table 2

\%age inhibition of DPPH analysis at different concentrations of AJEAE and IC50 values

\begin{tabular}{|lllll|}
\hline $\begin{array}{l}\text { Concentrations } \\
\mathbf{m g} / \mathbf{m l}\end{array}$ & $\begin{array}{l}\text { \% inhibition of ascorbic } \\
\text { acid }\end{array}$ & $\begin{array}{l}\text { IC 50 value } \\
\mathbf{m g} / \mathbf{m l}\end{array}$ & $\begin{array}{l}\text { \% inhibition of } \\
\text { AJEAE }\end{array}$ & $\begin{array}{l}\text { IC 50 value } \\
\mathrm{mg} / \mathrm{ml}\end{array}$ \\
\hline 0.2 & 31.5 & 0.54 & 19.523 & 0.77 \\
\hline 0.4 & 40.8 & & 27.879 \\
\hline 0.6 & 52.8 & & 39.156 \\
\hline 0.8 & 61.8 & & 43.175 \\
\hline 1 & 78.9 & & 69.470 \\
\hline
\end{tabular}

\section{Alpha amylase inhibition activity}

All concentrations of AJEAE were tested on a-amylase enzyme. The a-amylase activity of the AJEAE exhibited inhibitions of $71.8 \%$ at maximum concentration of $1 \mathrm{mg} / \mathrm{ml}$ with IC 50 value of 0.51 . The IC 50 value for standard (acarbose) was $0.29 \mathrm{mg} / \mathrm{ml}$ (Table 3).

Table 3

\%age inhibition of a-amylase analysis at different concentrations of AJEAE and IC50 values

\begin{tabular}{|lllll|}
\hline $\begin{array}{l}\text { Concentrations } \\
\mathrm{mg} / \mathrm{ml}\end{array}$ & $\begin{array}{l}\text { \% inhibition of } \\
\text { acrbose }\end{array}$ & $\begin{array}{l}\text { IC 50 value } \\
\mathrm{mg} / \mathrm{ml}\end{array}$ & $\begin{array}{l}\text { \% inhibition of } \\
\text { AJEAE }\end{array}$ & $\begin{array}{l}\text { IC 50 value } \\
\mathrm{mg} / \mathrm{ml}\end{array}$ \\
\hline 0.2 & 45.5 & 0.29 & 30.9 & 0.51 \\
\hline 0.4 & 56 & & 45.7 \\
\hline 0.6 & 62.8 & & 57.6 \\
\hline 0.8 & 76.5 & & 65.9 \\
\hline 1 & 85.9 & & 71.8 \\
\hline
\end{tabular}


Fasting blood glucose level in alloxan induced diabetic rats significantly increased from week 0 to week 4 as compared to normal control. After treatment with GL and AJEAE, FBG levels were significantly decreased from week 0 to 4 . Serum glucose and $\mathrm{HbA} 1 \mathrm{c}$ levels were noticeably $(\mathrm{p}<0.001)$ augmented in all diabetic rats with comparison to normal control group. However, administration of GL and AJEAE graded doses reduced the levels of serum glucose and $\mathrm{HbA} 1 \mathrm{c}$ dose dependently in comparison to diabetic control group. Serum insulin levels were significantly $(p<0.001)$ elevated in GL and AJEAE treated rats in comparison to diabetic control group (Fig. 2).

\section{Effects of AJEAE on serum lipid profile}

Substantial $(P<0.05)$ raise was detected in serum TC, TG, LDL and VLDL while decrease in HDLvalues in the alloxan treated group compared to the control group. Furthermore, AJEAE treatment showed an anti-lipidemic effect and produced significant $(P<0.05)$ reduction in $T C, T G, V L D L, L D L$ and increase in HDL levels as compared to DC group (Table 4).

Table 4 Effect of AJEAE on serum lipid profile

\begin{tabular}{|c|c|c|c|c|c|}
\hline \multirow[b]{2}{*}{ Parameter } & \multicolumn{5}{|l|}{ Groups } \\
\hline & NC & $\mathrm{DC}$ & GL & $\begin{array}{l}\text { AJEAE } \\
250 \mathrm{mg} / \mathrm{kg}\end{array}$ & AJEAE $500 \mathrm{mg} / \mathrm{kg}$ \\
\hline $\begin{array}{l}\text { Cholestrol } \\
\mathrm{mg} / \mathrm{dl}\end{array}$ & $70.50 \pm 0.4041$ & $198.7 \pm 1.856^{\mathrm{a}^{\star \star \star}}$ & $88.27 \pm 1.317^{\mathrm{b} * \star \star}$ & $103.3 \pm 3.351^{b \star \star \star}$ & $92.33 \pm 1.734^{\mathrm{b} * \star \star}$ \\
\hline $\begin{array}{l}\text { Triglycerides } \\
\text { mg/dl }\end{array}$ & $73.20 \pm 1.172$ & $139.7 \pm 2.771^{a^{\star \star \star}}$ & $85.63 \pm 0.6360^{b * \star \star}$ & $129.3 \pm 0.9333^{b *}$ & $104.4 \pm 3.225^{b \star \star \star}$ \\
\hline $\mathrm{HDL} \mathrm{mg/dl}$ & $28.80 \pm 0.3606$ & $17.20 \pm 0.1732^{a \star \star \star}$ & $21.87 \pm 0.1202^{b \star \star \star}$ & $18.80 \pm 0.1528^{b * *}$ & $22.37 \pm 0.2404^{b \star \star \star}$ \\
\hline LDL mg/dl & $34.97 \pm 0.1453$ & $155.5 \pm 2.754^{a \star \star \star}$ & $55.30 \pm 0.2887^{b * \star \star}$ & $95.33 \pm 2.609^{b * * \star}$ & $81.03 \pm 3.295^{b \star \star \star}$ \\
\hline VLDL mg/dl & $17.93 \pm 0.2963$ & $33.43 \pm 0.2728^{a \star \star \star}$ & $21.63 \pm 0.5207^{b * \star *}$ & $29.67 \pm 0.5207^{b * *}$ & $24.03 \pm 0.8110^{\mathrm{b} \star \star \star}$ \\
\hline
\end{tabular}

Values are illustrated as mean \pm SEM; $n=15$ per group. Statistical comparisons "a" compared with normal control, "b" compared with diabetic control. * represent significance at $p<0.05$, ** represent significance at $p<0.01$, *** represent significance at $p<0.001$

\section{Effects of AJEAE on serum inflammatory markers}

Figure 3 describes the inflammatory response of hepatic and pancreatic tissues in all groups. Results showed significant $(p<0.001)$ elevation of TNF- $a$ and IL-6 levels after diabetes induction compared to control group. Though, $\mathrm{GL}$ and AJEAE $(250 \mathrm{mg} / \mathrm{kg} ; 500 \mathrm{mg} / \mathrm{kg})$ treatment significantly $(\mathrm{p}<0.001)$ decreased the inflammatory markers compared to diabetic group. 


\section{Effects of AJEAE on oxidative stress markers}

As shown in Fig. $4-5$, significant $(p<0.001)$ decline was observed in hepatic and pancreatic antioxidant enzymes (SOD, GPx and CAT) in alloxan treated group compared to control group. However, GL and AJEAE $(250 \mathrm{mg} / \mathrm{kg}$; $500 \mathrm{mg} / \mathrm{kg}$ ) treatments resulted in remarkable increase in the antioxidant levels with respect to diabetic group ( $p<$ 0.001). About non-enzymatic oxidative stress markers, substantial increase of LPO and NO contents in hepatic and pancreatic tissues were observed in diabetic group in comparison with control group. However, treatment with GL and AJEAE $(250 \mathrm{mg} / \mathrm{kg} ; 500 \mathrm{mg} / \mathrm{kg})$ in diabetic rats decreased LPO and NO levels in both tissues with respect to diabetic group.

\section{Histopathological results}

The pancreatic tissues of NC group showed a normal structure with contact islets of Langerhans (Fig. 6a) while in DC group the islets of Langerhans exhibited signs of atrophy as well as shrinkage, additionally severe damage to both $\beta$ cells and pancreatic islets. However, GL and AJEAE treated groups preserved the pancreatic tissues, efficiently attenuated the pancreatic lesions and improved $\beta$-cells mass. Damage of the pancreatic $\beta$-cells is main symptom in diabetes and consequently caused to impairment of insulin production. Our findings suggest that AJEAE improved the histoarchitecture of pancreatic beta cells and insulin release (Fig. 6a-e).

\section{Discussion}

Diabetes mellitus is accompanied by noteworthy changes in lipid and glucose metabolism and the stimulation of oxidative stress which are contributed in the development of DM related complications (Albasher et al. 2020). Different lifestyle and dietary factors including physical inactivity, weight gain, obesity and low fiber diet plays substantial role in diabetes development (Idm'hand et al. 2020). Our findings revealed the occurrence of various flavonoids and phenols in AJEAE (Table 1). Flavonoids are major bioactive compounds and according to previous literature they have property

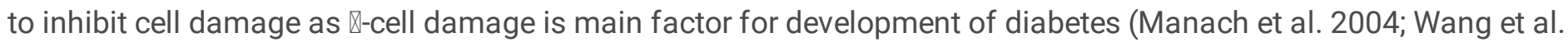
2018). Our results indicated that AJEAE contains high concentration of flavonoids i.e. quercetin and kaempferol which have strong anti-oxidant and anti-inflammatory activities (Gavamukulya et al.2014).

Supporting the results of preceding research studies, ferulic acid and sinapic acid have antioxidant, anti-inflammatory, anti-microbial, anticancer and antidiabetic effects (Zduńska et al. 2018; Chen 2016). Chlorogenic acid is proved to possess antioxidant, anti-inflammatory, antibacterial, free radical scavenger activities and also has property to improve glucose homeostasis (Majeed et al. 2021; Naveed et al. 2018). Vanillic acid ameliorates hyperglycemia induced oxidative stress and inflammation ( $\mathrm{Ji}$ et al. 2020) and syringic acid reduces oxidative damages (Sabahi et al. 2020). Gallic acid increases insulin release and has antioxidant and anti-inflammatory properties (Majeed et al. 2021; Kahkeshani et al. 2019). Cinnamic acid is linked with a beneficial influence on management of diabetes and its complications (Adisakwattana 2017). Interestingly, all the phenol and flavonoid compounds detected in AJEAE are responsible to be therapeutically effective against diabetes due to their antioxidant and anti-hyperglycemic activities.

In-vitro antioxidant activity of AJEAE was evaluated by DPPH. The result of present study revealed that AJEAE contains bioactive compounds with high capability to scavenge free radicals. These phytochemicals could be phenolic and flavonoids which might have potent antioxidant activities. Antidiabetic potential (in vitro) was evaluated by aamylase inhibition assay, a-amylase is carbohydrate digesting enzyme required to hydrolyze complex polysaccharides to simple's sugars. We found that AJEAE exhibited $71.8 \%$ inhibition of a-amylase enzyme activity (Table 3 ). This 
enzyme inhibition has confirmed to be effective approach in controlling the postprandial sugar levels (Ononamadu et al. 2019).

In the current study, alloxan monohydrate induced diabetes by direct damage to pancreatic $\beta$-cells, resulting in loss of insulin secretion and hyperglycemia. We found remarkable reduction in FBG, serum glucose and improvement in serum insulin levels in AJEAE and GL treated groups. The hypoglycemic activity of AJEAE may refer to the inhibition of free radical species formation induced by alloxan. In agreement to previous research studies, plant extracts containing high flavonoids and polyphenol compounds have potential to increase insulin secretion, regenerative potential of $\beta$-cells, by inhibiting ATP sensitive $\mathrm{K}+$ channels like Glibenclimide (Arunachalam and Parimelazhagan 2014). Flavonoids have property to inhibit cAMP phosphodiesterase which is responsible for insulin secretion (Albasher et al. 2020).To assess the long term glycemic control during diabetic treatment $\mathrm{HbA1c}$ is one of most important marker (Yazdanpanah et al. 2017; Chehregosha et al. 2019). This study observed significant decrease in HbA1c levels in GL and AJEAE treated groups (Fig. 2).

Diabetes mellitus is connected with augmented morbidity and mortality that results from cardiovascular diseases (Lamacchia and Sorrentino 2021). In DM, metabolism of lipids is also disturbed. Altered lipid profile is known to establish danger for atherosclerosis in diabetes. So control of lipid profile is also vital along with the glucose reduction to reduce the risk of diabetes. However treatment with AJEAE stabilized the lipid profile through reduction in TC, TG, LDL and VLDL as well as significant raise in HDL levels in dose dependent manner. The hypolipidemic effect of AJEAE may mention to the bioactive compounds, flavonoids and phenols, which potentiate the release of insulin from pancreatic beta cells and improve the glucose oxidation (Albasher et al. 2020).

Oxidative stress is a proposed mechanism for initiation and development of diabetes, as hyperglycemia is strongly linked with increased superoxide generation via the mitochondrial system (Hassan et al. 2015; Tiwari et al. 2013). According to our results, AJEAE notably amended the pancreatic and hepatic antioxidant markers (SOD, GPx and CAT). Alloxan significantly increased the concentration of MDA and NO compared to the control group, which indicated powerful oxidative stress due to radical production (Anwar and Meki 2003). AJEAE treatment results in significant reduction of MDA and NO level as compared to diabetic group.

There is a significant link between inflammation and $\beta$-cell damage that signifies its association in the pathogenesis of DM. Hyperglycemia results in the formation of advanced glycation products which are related with inflammation. TNF$a$ and IL-6 are suggested to increase the intensity and occurrence of diabetic complications (Albasher et al. 2020). In this study we further evaluated the pro-inflammatory cytokines levels, TNF-a and IL- 6 as these cytokines are recognized to show vital role in development of insulin resistance (Ramadan et al. 2017). In diabetic rats, elevated levels of serum TNF- $a$ and IL- 6 were detected; instead AJEAE considerably $(p<0.001)$ reduced the TNF- $a$ and IL- 6 levels in dose dependent manner. Histopathological analysis has revealed that AJEAE considerably normalized the histoarchitecture of pancreatic tissues. Interestingly AJEAE treatment showed significant pancreatic beta cells regenerative potential due to the dramatic raise in pancreatic beta cell population and suppression in unusual histological changes in comparison to DC group (Fig. 6a-e). Concerning the mechanism through which AJEAE can improve the histoarchitecture of pancreatic beta cells, earlier research studies have found that flavonoids and phenolics exhibit significant contribution in regeneration of $\beta$-cells (Elshamy et al. 2017). The outcomes of present study have proposed the hypoglycemic, hypolipidemic, antioxidant and pancreatic beta cells regenerative properties of Acacia jacquemontii through its protective role in $\beta$-cells mass and functioning along with observable improvement in glycemic, lipidemic status and suppression of oxidative stress.

\section{Conclusion}


For the first time, results from our study have reported the role of phenols and flavonoids from AJEAE in downregulating the hyperglycemia via modulation of glycemic, lipedemic, anti-inflammatory and anti-oxidant defense markers. Furthermore, AJEAE also showed strong regenerative pancreatic beta cells potential through improvement in histoarchitechture of pancreatic $\beta$-cells. The findings of present study highlight the therapeutic significance of Acacia jacquemontii in the management of hyperglycemia.

\section{Declarations}

Compliance with ethical standards: Experimental protocol was planned according to laboratory animal care guidelines permitted by Graduate studies Research Board, UAF Pakistan. Ethical certificate was issued by institutional biosafety and bioethics committee with letter no. 1739/ORIC for the conduct of in-vivo experiment.

Consent to participate: Not applicable

Consent to publish: Not applicable

Data availability: The datasets used and/or analysed during the current study are available from the corresponding author on reasonable request.

Declaration of interest: The authors declare that they have no conflict of interest.

Funding: Not applicable

Author contribution: A.M and W.M made experimental design, participated in data collection, analyzed the total flavonoid and phenolic compounds in the plant extract and performed the histopathological examination. F.M and N.F analyzed and interpreted biochemical measurements. All authors read and approved the final manuscript.

Acknowledgement: Authors acknowledged the respected lab staff of Institute of Physiology and Pharmacology, University of Agriculture, Faisalabad, Pakistan for collaboration in the lab and research facilities.

\section{References}

1. Adisakwattana S (2017) Cinnamic acid and its derivatives: mechanisms for prevention and management of diabetes and its complications. Nutrients 9(2):163. https://doi.org/10.3390/nu9020163

2. Albasher G, Alwahaibi M, Abdel-Daim MM, Alkahtani S, Almeer R (2020) Protective effects of Artemisia judaica extract compared to metformin against hepatorenal injury in high-fat diet/streptozotocine-induced diabetic rats. Environ Sci Pollut Res 27(32):40525-40536. https://doi.org/10.1007/s11356-020-09997-2

3. Anwar MM, Meki A-RMA (2003) Oxidative stress in streptozotocin induced diabetic rats: effects of garlic oil and melatonin. Comp Biochem Physiol A Mol Integr Physiol 135:539-547. https://doi.org/10.1016/S10956433(03)00114-4

4. Arise RO, Ganiyu Al, Oguntibeju OO (2014) Lipid profile, antidiabetic and antioxidant activity of Acacia ataxacantha bark extract in streptozotocin-induced diabetic rats. Antioxidant-Antidiabetic Agents Human Health 3-24.http://dx.doi.org/10.5772/57029

5. Arumugam G, Manjula P, Paari N (2013) A review: Anti diabetic medicinal plants used for diabetes mellitus. J Acute Dis 2(3):196-200. https:// doi.org/10.1016/S2221-6189(13)60126-2

6. Arunachalam K, Parimelazhagan T (2014) Antidiabetic and enzymatic antioxidant properties from methanol extract of Ficustalboti bark on diabetic rats induced by streptozotocin. Asian Pac J Reprod 3(2):97-105. 
https://doi.org/10.1016/S2305-0500(14)60011-7

7. Aryal S, Baniya MK, Danekhu K, Kunwar P, Gurung R, Koirala N (2019) Total phenolic content, flavonoid content and antioxidant potential of wild vegetables from Western Nepal. Plants 8(4):96.

https://doi.org/10.3390/plants8040096

8. Ashfaq K, Choudhary BA, Uzair M, Hussain SN, Ghaffari MA, Sarwar W, Manzoor M (2016) Antipyretic, analgesic and anti-inflammatory activities of methanol extract of root bark of Acacia jacquemontii Benth (Fabaceae) in experimental animals. Trop J Pharm Res 15(9):1859-1863. doi:10.4314/tjpr.v15i9.7

9. Ashraf A, Sarfraz RA, Rashid MA, Shahid M (2015) Antioxidant, antimicrobial, antitumor, and cytotoxic activities of an important medicinal plant (Euphorbia royleana) from Pakistan. J Food Drug Anal 23(1):109-115. https://doi.org/10.1016/j.jfda.2014.05.007

10. Calixto JB (2019) The role of natural products in modern drug discovery. An Acad Bras Cienc 91. https://doi.org/10.1590/0001-3765201920190105

11. Chehregosha $H$, Khamseh ME, Malek M, Hosseinpanah F, Ismail-Beigi $F$ (2019) A view beyond HbA1c: role of continuous glucose monitoring. Diabetes Ther 10(3):853-863. https://doi.org/10.1007/s13300-019-0619-1

12. Chen C (2016) Sinapic acid and its derivatives as medicine in oxidative stress-induced diseases and aging. Oxid Med Cell Longev 2016. https://doi.org/10.1155/2016/3571614

13. Chen SL, Yu H, Luo HM, Wu Q, Li CF, Steinmetz A (2016) Conservation and sustainable use of medicinal plants: problems, progress, and prospects. Chin Med J 11(1):1-10. doi 10.1186/s13020-016-0108-7

14. Choudhary K, Singh M, Shekhawat NS (2009) Ethnobotany of Acacia jacquemontii Benth.-An Uncharted Tree of Thar Desert, Rajasthan, India. Ethnobot Leaflets 2009(6):1

15. Choudhury H, Pandey M, Hua CK, Mun CS, Jing JK, Kong L, Ern LY, Ashraf NA, Kit SW, Yee TS, Pichika MR (2018) An update on natural compounds in the remedy of diabetes mellitus: A systematic review. J Trad Complement Med 8(3):361-376. https://doi.org/10.1016/j.jtcme.2017.08.012

16. Eslami H, Batavani RA, Asr S (2015) Changes of stress oxidative enzymes in rat mammary tissue, blood and milk after experimental mastitis induced by E. coli lipopolysaccharide. In Veterinary Research Forum, 6 (2) 131 Faculty of Veterinary Medicine, Urmia University, Urmia, Iran

17. Elshamy Al, El-Shazly M, Yassine YM, El-Bana MA, Farrag AR, Nassar MI, Singab AN, Noji M, Umeyama A (2017) Phenolic constituents, anti-inflammatory and antidiabetic activities of Cyperuslaevigatus L. Pharmacogn J 9(6). doi:10.5530/pj.2017.6.129

18. Gavamukulya Y, Abou-Elella F, Wamunyokoli F, AEl-Shemy H (2014) Phytochemical screening, anti-oxidant activity and in vitro anticancer potential of ethanolic and water leaves extracts of Annona muricata (Graviola). Asian Pac J Trop Med 7:S355-S363. https:// doi.org/10.1016/S1995-7645(14)60258-3

19. Hammeso WW, Emiru YK, Ayalew Getahun K, Kahaliw W (2019) Antidiabetic and antihyperlipidemic activities of the leaf latex extract of Aloe megalacantha baker (Aloaceae) in streptozotocin-induced diabetic model. Evid Based Complement Alternat Med 2019. https://doi.org/10.1155/2019/8263786

20. Hassan SK, EL-Sammad NM, MousaAM (2015) Hypoglycemic and antioxidant activities of Caesalpinia ferra Martius leaf extract in streptozotocin-induced diabetic rats Asian Pac. J Trop Med 5:462-473. https://doi.org/10.1016/j.apjtb.2015.03.004

21. Idm'hand E, Msanda F, Cherifi K (2020) Ethnopharmacological review of medicinal plants used to manage diabetes in Morocco. Clin Phytoscience 6:1-32. https://doi.org/10.1186/s40816-020-00166-z

22. Imtiaz SM, Aleem A, Saqib F, Ormenisan AN, Elena Neculau A, Anastasiu CV (2019) The Potential Involvement of an ATP-Dependent Potassium Channel-Opening Mechanism in the Smooth Muscle Relaxant Properties of Tamarix

Page $11 / 18$ 
dioica Roxb. Biomolecules 9(11):722. https://doi.org/10.3390/biom9110722

23. Ji G, Sun R, Hu H, Xu F, Yu X, Veeraraghavan VP, Mohan SK, Chi X (2020) Vannilic acid ameliorates hyperglycemiainduced oxidative stress and inflammation in streptozotocin-induced diabetic rats. J King Saud Univ Sci 32(7):2905-2911. https://doi.org/10.1016/j.jksus.2020.04.010

24. Kahkeshani N, Farzaei F, Fotouhi M, Alavi SS, Bahramsoltani R, Naseri R, Momtaz S, Abbasabadi Z, Rahimi R, Farzaei MH, Bishayee A (2019) Pharmacological effects of gallic acid in health and diseases: A mechanistic review. Iran J Basic Med Sci 22(3):225. doi:10.22038/ijbms.2019.32806.7897

25. Khan MF, Rawat AK, Khatoon S, Hussain MK, Mishra A, Negi DS (2018) In vitro and in vivo antidiabetic effect of extracts of Melia azedarach, Zanthoxylum alatum, and Tanacetum nubigenum. Integr Med Res 7(2):176-183. https://doi.org/10.1016/j.imr.2018.03.00

26. Lamacchia O, Sorrentino MR (2021) Diabetes mellitus, arterial stiffness and cardiovascular disease: clinical implications and the influence of SGLT2i. Curr Vasc Pharmacol 19(2):233-240.

https://doi.org/10.2174/1570161118666200317150359

27. Majeed W, Aslam B, Iftikhar A, Awan AM, Javed F, Daud M, Shahab N, Syed M, Iqbal H (2021) Acacia nilotica polyphenol extract restores glucose homeostasis by upregulating the insulin secretion and lowering the oxidative stress through down regulation of c-Jun N-terminal kinase (JNK) signaling cascade. J King Saud Univ Sci 33(5):101474. https:// doi.org/10.1016/j.jksus.2021.101474

28. Majeed W, Khaliq T, Aslam B, Khan JA (2018) Polyherbal Formulation Prevents Hyperglycemia by Modulating the Biochemical Parameters and Upregulating the Insulin Signaling Cascade in Alloxan Induced Hyperglycemic Rats. Pak Vet J 38(2):121-126. doi:10.29261/pakvetj/2018.035

29. Manach C (2004) Polyphenols: food sources and bioavailability. Am J Clin Nutr 79:727-747. https://doi.org/10.1093/ajcn/79.5.727

30. MogoleL, Omwoyo W, Mtunzi F (2020) Phytochemical screening, anti-oxidant activity and a-amylase inhibition study using different extracts of loquat (Eriobotrya japonica) leaves. Heliyon 6(8):04736. https://doi.org/10.1016/j.heliyon.2020.e04736

31. Moradi B, Abbaszadeh S, Shahsavari S, Alizadeh M, Beyranvand F (2018) The most useful medicinal herbs to treat diabetes. Biomed Res Ther 5(8):2538-2551. doi:10.15419/bmrat.v5i8.463

32. Naveed M, Hejazi V, Abbas M, Kamboh AA, Khan GJ, Shumzaid M, Ahmad F, Babazadeh D, FangFang X, Modarresi-Ghazani F, WenHua L (2018) Chlorogenic acid (CGA): A pharmacological review and call for further research. Biomed Pharmacother 97:67-74. https://doi.org/10.1016/j.biopha.2017.10.064

33. Ononamadu CJ, Alhassan AJ, Imam AA, Ibrahim A, Ihegboro GO, Owolarafe AT, Sule MS (2019) In vitro and in vivo anti-diabetic and anti-oxidant activities of methanolic leaf extracts of Ocimumcanum. Casp J Intern Med 10(2):162. doi:10.22088/cjim.10.2.162

34. Phuyal N, Jha PK, Raturi PP, Rajbhandary S (2020) Total phenolic, flavonoid contents, and antioxidant activities of fruit, seed, and bark extracts of Zanthoxylum armatum DC. Scientific World J. https://doi.org/10.1155/2020/8780704

35. Ramadan BK, Schaalan MF, Tolba AM (2017) Hypoglycemic and pancreatic protective effects of Portulacaoleracea extract in alloxan induced diabetic rats. BMC Complement Altern Med 17(1):1-10. doi:10.1186/s12906-016-1530-1

36. Rasool F, Murtaza G, Zeshan M, Habib R, Yousaf MM, Ayub MM, Ayub MA, Sardar K, Irshad HA (2016) Comprehensive review on ecology and ethnobotany of Acacias and Acacia jacquemontii Benth in dry environment. IJAR 2(12):103-109

Page 12/18 
37. Rasool F, Ishaque M, Yaqoob S, Tanveer A (2017) Chemical composition and ethnobotanical uses of Acacia jacquemontii Benth. in the Thal desert in Pakistan. Bois forets des tropiques 331:67-76.

https://doi.org/10.19182/bft2017.331.a31327 ) :. doi

38. Sabahi Z, Khoshnoud MJ, Khalvati B, Hashemi SS, Farsani ZG, Gerashi HM, Rashedinia M (2020) Syringic acid improves oxidative stress and mitochondrial biogenesis in the liver of streptozotocin-induced diabetic rats. Asian Pac J Trop Biomed 10(3):111. doi:10.4103/2221-1691.276317

39. Salehi B, Ata A, Anil Kumar V, Sharopov N, Ramírez-Alarcón F, Ruiz-Ortega K, Abdulmajid Ayatollahi A, Valere Tsouh Fokou S, Kobarfard P, Amiruddin Zakaria F, Iriti Z M (2019) Antidiabetic potential of medicinal plants and their active components. Biomolecules 9(10):551. https://doi.org/10.3390/biom9100551

40. Sangeetha R, Vedasree N (2012) In vitro a-amylase inhibitory activity of the leaves of Thespesia populnea. Int Sch Res Notices 2012. doi:10.5402/2012/515634

41. Sathasivampillai SV, Rajamanoharan PR, Munday M, Heinrich M (2017) Plants used to treat diabetes in Sri Lankan Siddha Medicine-An ethnopharmacological review of historical and modern sources. J Ethnopharmacol 198:531-599. https://doi.org/10.1016/j.jep.2016.07.053

42. Takahara S, Hamilton HB, Neel JV, Kobara TY, Ogura Y, Nishimura ET (1960) Hypocatalasemia: a new genetic carrier state. J Clin Investig 39(4):610-619. https://doi.org/10.1172/JCl104075

43. Tiwari BK, Pandey KB, Abidi AB, Rizvi SI (2013) Markers of oxidative stress during diabetes mellitus. J Biomark 2013. https://doi.org/10.1155/2013/378790

44. Wang TY, Li Q, Bi KS (2018) Bioactive flavonoids in medicinal plants: Structure, activity and biological fate. Asian J Pharm Sci 13(1):12-23. https://doi.org/10.1016/j.ajps.2017.08.004

45. Yazdanpanah S, Rabiee M, Tahriri M, Abdolrahim M, Rajab A, Jazayeri HE, Tayebi L (2017) Evaluation of glycated albumin (GA) and GA/HbA1c ratio for diagnosis of diabetes and glycemic control: a comprehensive review. Crit Rev Clin Lab Sci 54(4):219-232. https://doi.org/10.1080/10408363.2017.1299684

46. Zduńska K, Dana A, Kolodziejczak A, Rotsztejn H (2018) Antioxidant properties of ferulic acid and its possible application. Skin Pharmacol Physiol 31(6):332-336. https://doi.org/10.1159/000491755

\section{Figures}




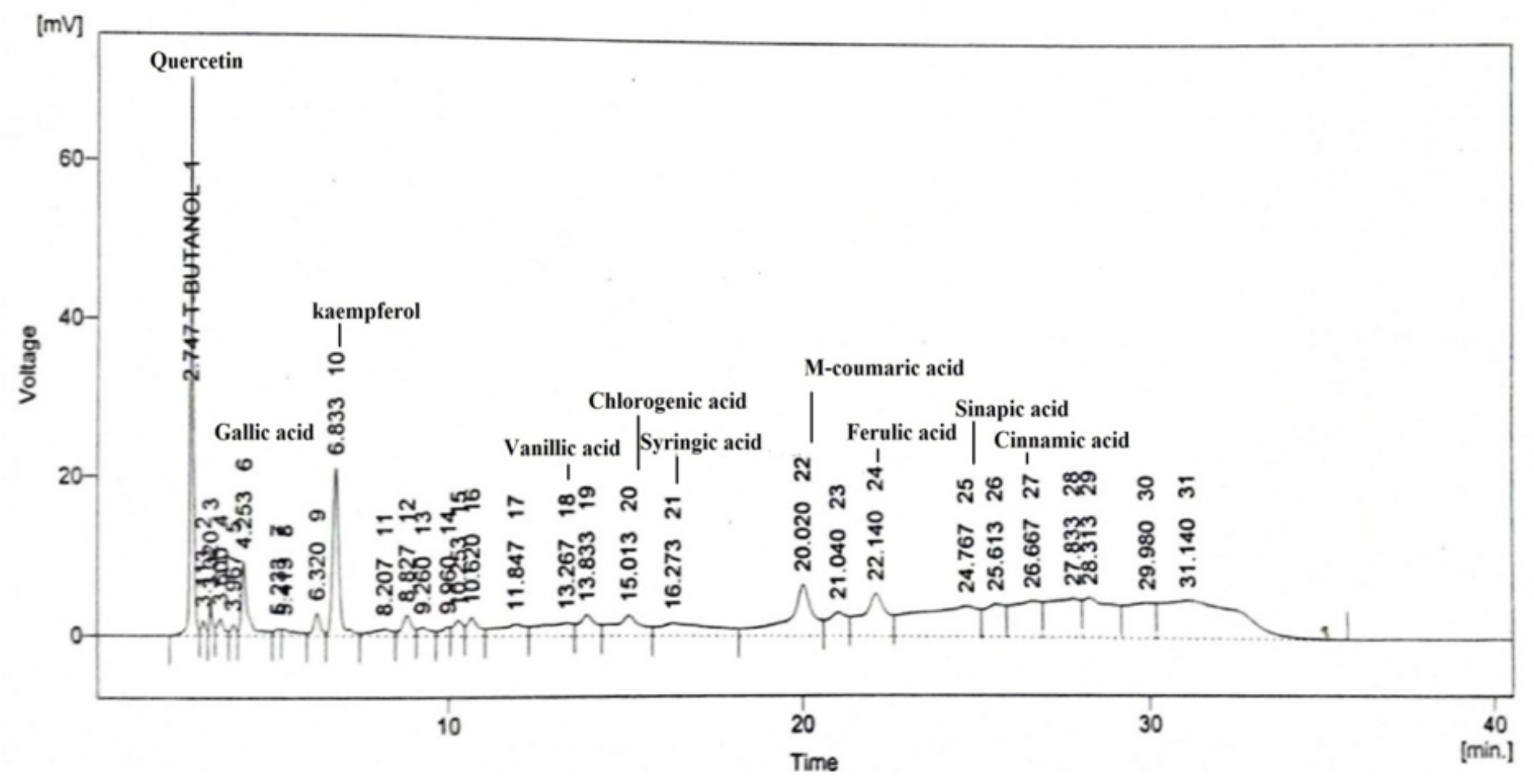

Figure 1

HPLC chromatogram profile of fingerprint of AJEAE
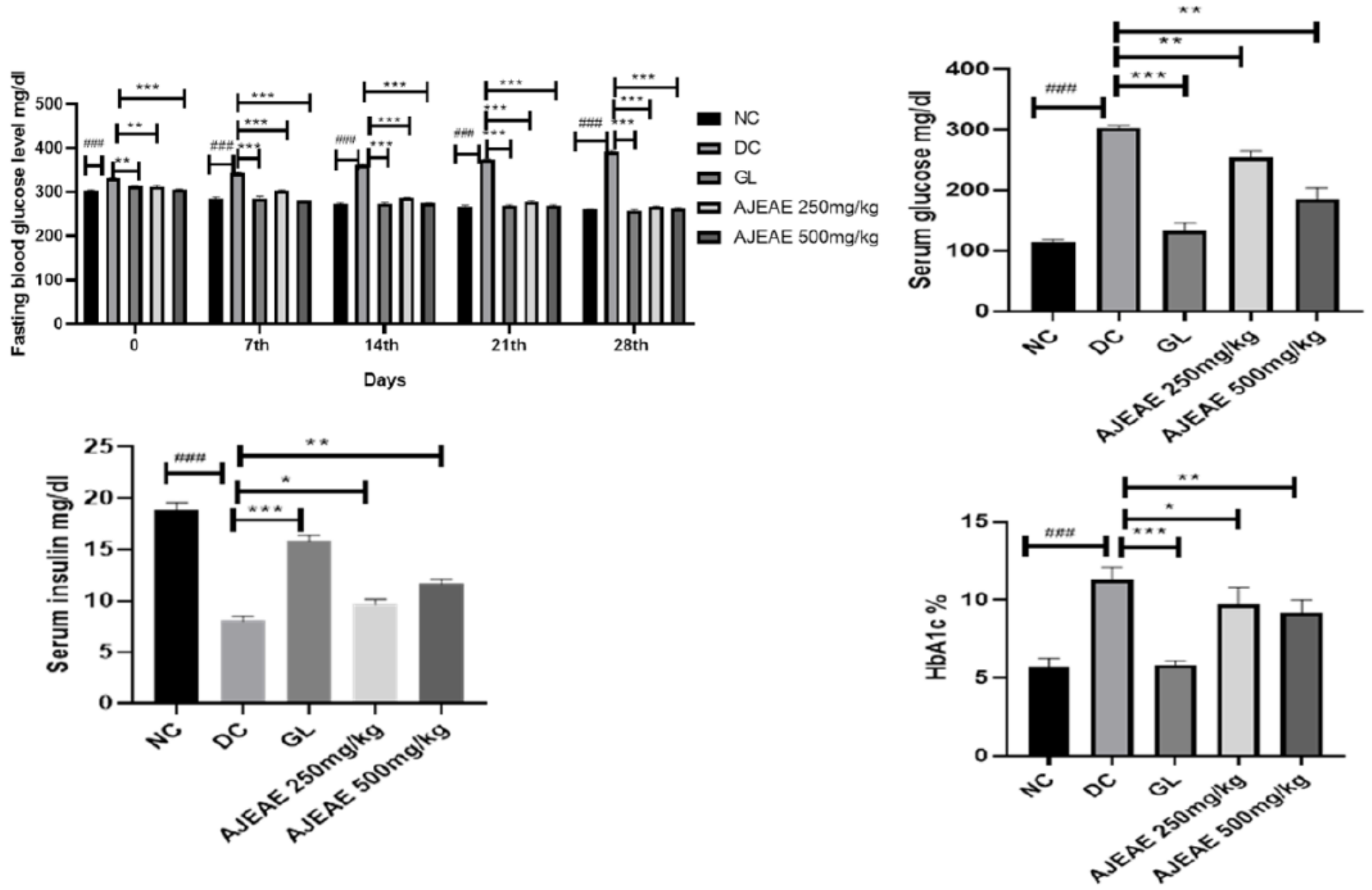
Figure 2

Effect of AJEAE on glycemic markers. \#\#\# shows $p<0.001$, represent significance at $p<0.05$, ** represent significance at $p<0.01$, $* \star \star$ represent significance at $p<0.001$. Abbreviations: $N C=$ normal control, $\mathrm{DC}=$ diabetic control, $\mathrm{GL}=$ Glibenclamide, AJEAE= A. jacquemontii ethyl acetate extract
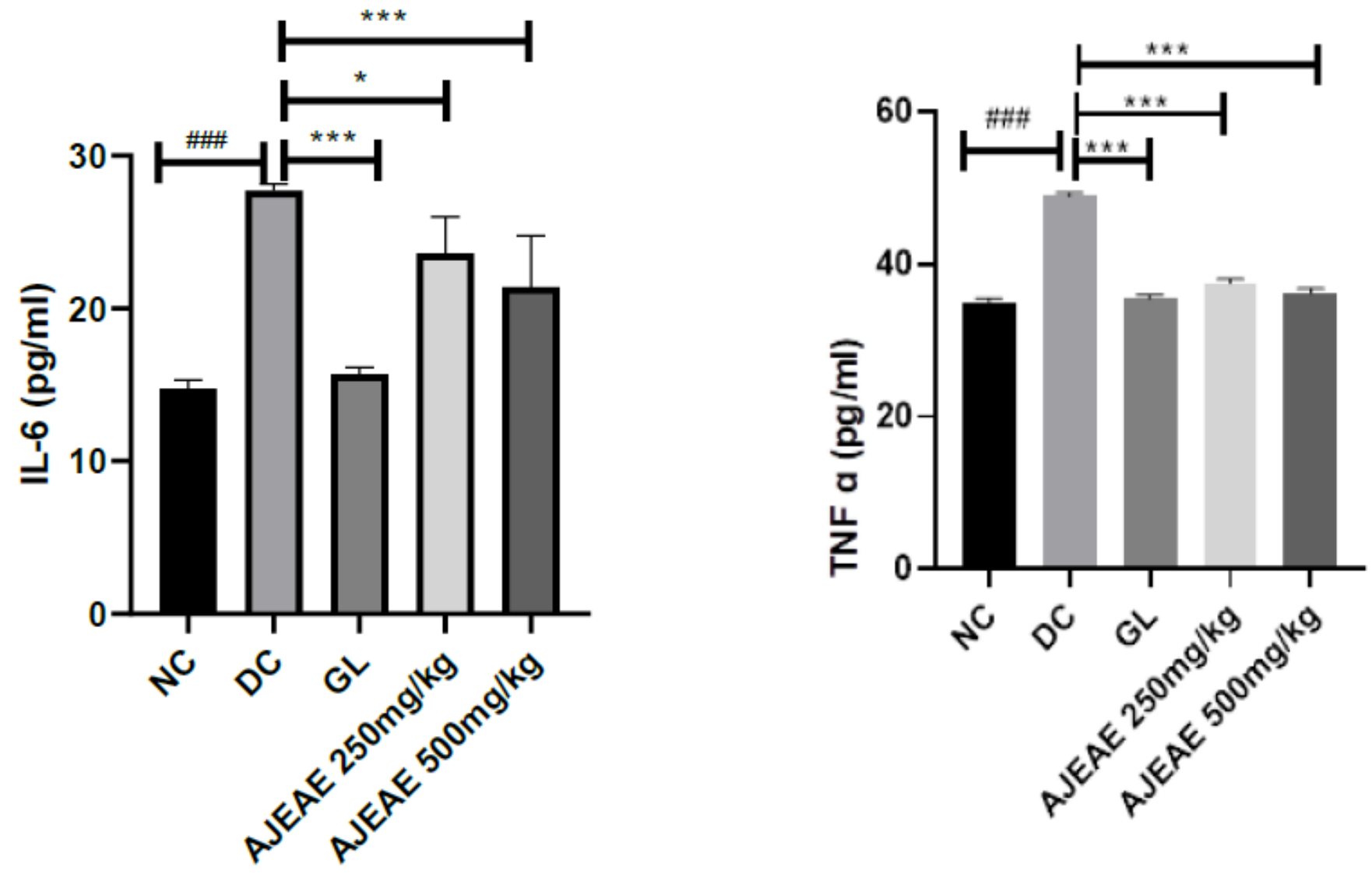

Figure 3

Effect of AJEAE on inflammatory markers. \#\#\# shows $p<0.001$, * represent significance at $p<0.05$, *** represent significance at $p<0.001$. Abbreviations: $N C=$ normal control, $D C=$ diabetic control, $G L=$ Glibenclamide, $A J E A E=A$. jacquemontii ethyl acetate extract 

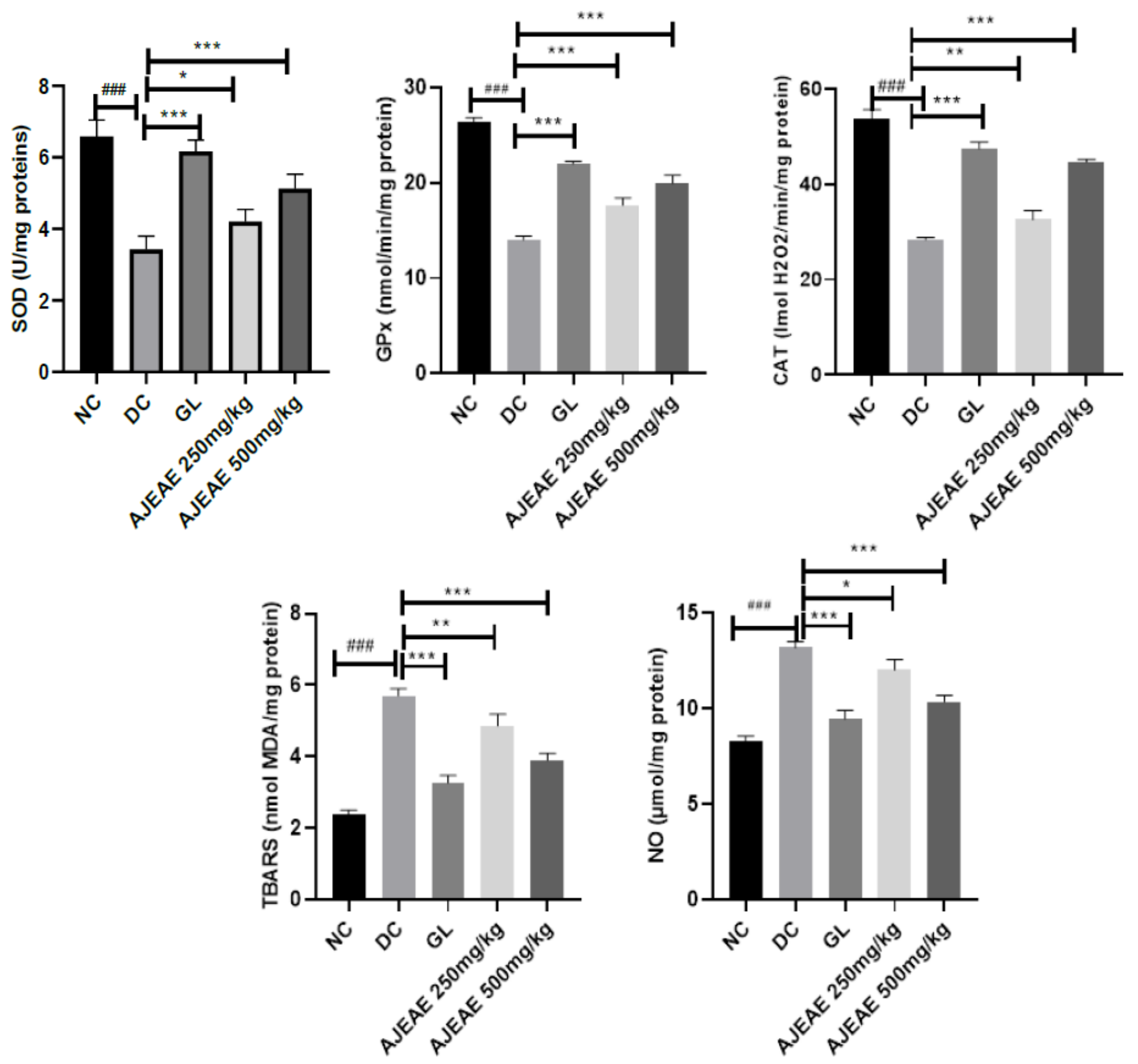

Figure 4

Effect of AJEAE on hepatic oxidative stress markers. \#\#\# shows $p<0.001$, * represent significance at $p<0.05$, ** represent significance at $\mathrm{p}<0.01, \star \star \star$ represent significance at $\mathrm{p}<0.001$. Abbreviations: $\mathrm{NC}=$ normal control, $\mathrm{DC}=$ diabetic control, $\mathrm{GL}=$ Glibenclamide, $\mathrm{AJEAE}=\mathrm{A}$. jacquemontii ethyl acetate extract 

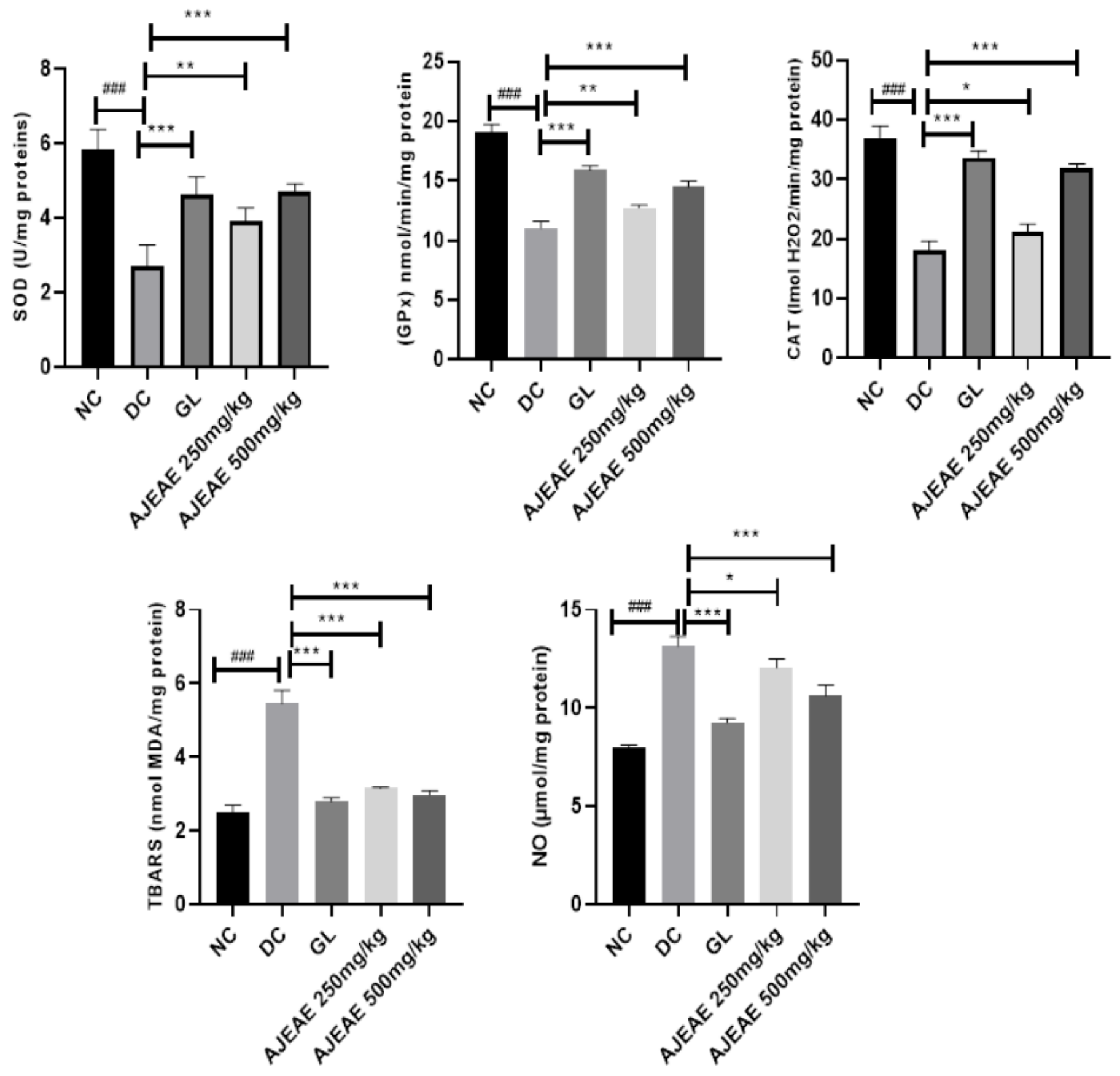

Figure 5

Effect of AJEAE on pancreatic oxidative stress markers. \#\#\# shows $p<0.001$, represent significance at $p<0.05$, ** represent significance at $p<0.01, * \star \star$ represent significance at $p<0.001$. Abbreviations: $N C=$ normal control, $D C=$ diabetic control, $\mathrm{GL}=$ Glibenclamide, $\mathrm{AJEAE}=\mathrm{A}$. jacquemontii ethyl acetate extract 


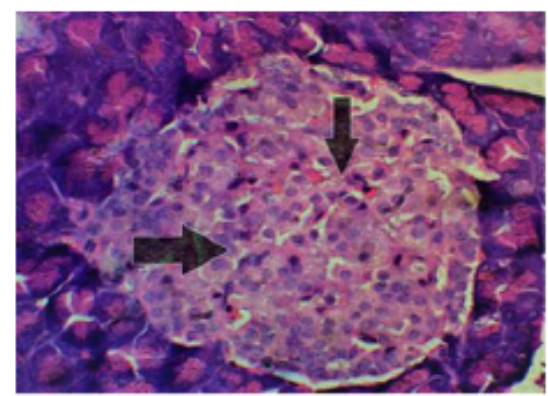

a

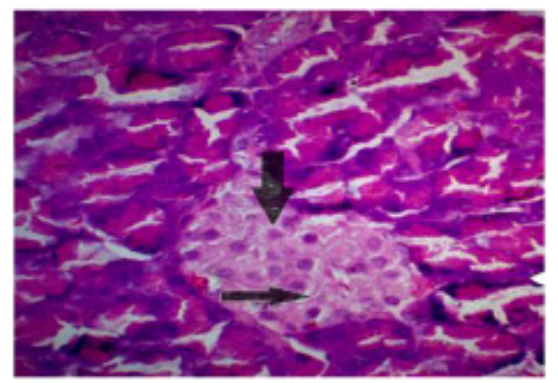

d

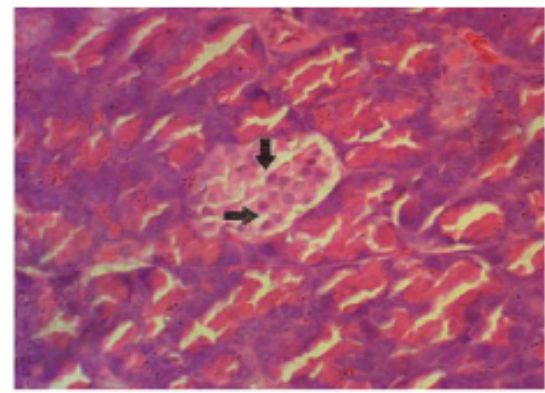

b

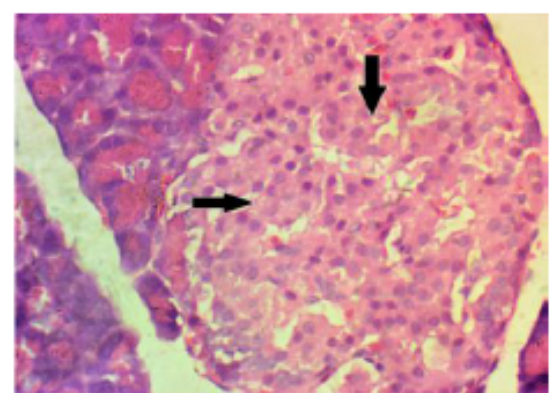

C

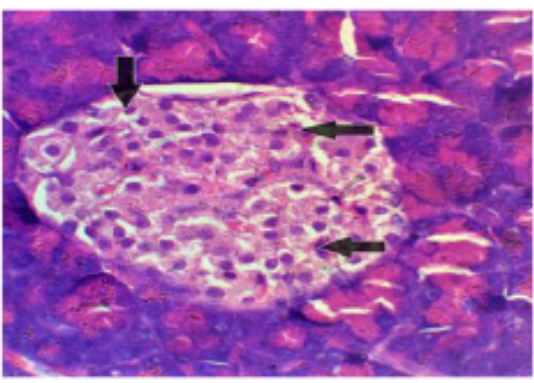

$\mathrm{e}$

Figure 6

(a-e) Photomicrograph of pancreas $(\mathrm{a})=\mathrm{NC},(\mathrm{b})=\mathrm{DC},(\mathrm{c})=\mathrm{GL},(\mathrm{d})=\operatorname{AJEAE}(250 \mathrm{mg} / \mathrm{kg}),(\mathrm{e})=\operatorname{AJEAE}(500 \mathrm{mg} / \mathrm{kg})$

\section{Supplementary Files}

This is a list of supplementary files associated with this preprint. Click to download.

- GraphicalAbstract.jpg 